\title{
Gerhard Zotz \\ How prevalent is crassulacean acid metabolism among vascular epiphytes?
}

Received: 24 March 2003 / Accepted: 18 September 2003 / Published online: 31 October 2003

(C) Springer-Verlag 2003

\begin{abstract}
The occurrence of crassulacean acid metabolism (CAM) in the epiphyte community of a lowland forest of the Atlantic slope of Panama was investigated. I hypothesized that CAM is mostly found in orchids, of which many species are relatively small and/or rare. Thus, the relative proportion of species with CAM should not be a good indicator for the prevalence of this photosynthetic pathway in a community when expressed on an individual or a biomass basis. In 0.4 ha of forest, 103 species of vascular epiphytes with 13,099 individuals were found. As judged from the $\mathrm{C}$ isotope ratios and the absence of Kranz anatomy, CAM was detected in 20 species $(19.4 \%$ of the total), which were members of the families Orchidaceae, Bromeliaceae, and Cactaceae. As predicted, the contribution of CAM epiphytes to the total number of individuals and to total biomass $\left(69.6 \mathrm{~kg} \mathrm{ha}^{-1}\right)$ was considerably lower (3.6\% or 466 individuals and, respectively, $3.0 \%$ or $2.1 \mathrm{~kg}$ ha $\left.^{-1}\right)$.
\end{abstract}

Keywords Biomass $\cdot$ Bromeliaceae $\cdot$ Cactaceae Crassulacean acid metabolism - Orchidaceae

\section{Introduction}

For decades, the occurrence of crassulacean acid metabolism (CAM) was associated primarily with succulent and shrub-like plants from arid habitats (Osmond et al. 1982). Particularly the work of Nuernbergk (1960), Coutinho (1969) and Winter (1985) initiated a change in our perception of a "typical" CAM plant. We now know that

\footnotetext{
G. Zotz $(\bowtie)$

Botanisches Institut der Universität Basel,

Schönbeinstrasse 6,

4056 Basel, Switzerland

e-mail: gerhard.zotz@unibas.ch

Tel.: +41-61-2673511

Fax: +41-61-2673504

G. Zotz

Smithsonian Tropical Research Institute,

Balboa, Panama
}

the majority of plant species using this water-preserving photosynthetic pathway live in trees as epiphytes. In a recent review on the taxonomic occurrence of CAM, Winter and Smith (1996) pointed out that Orchidaceae present the greatest uncertainty concerning the number of CAM plants. This family with $>800$ genera and at least 20,000 species (Dressler 1981) is estimated to have 7,000, mostly epiphytic, CAM species (Winter and Smith 1996), which alone would account for almost $50 \%$ of all CAM plants. A number of studies, mostly using stable isotope techniques, documented a steady increase in the proportion of CAM plants among local epiphyte floras from wet tropical rainforest and moist tropical forests to dry forests. For example, while about $25 \%$ of the epiphytic orchid species in New Guinean and Australian rain forests showed CAM (Winter et al. 1983; Earnshaw et al. 1987), this proportion increased to $40 \%$ in a moist forest in Panama (Zotz and Ziegler 1997) and reached $100 \%$ in a Mexican dry forest (Mooney et al. 1989).

While it seems unlikely that future studies will challenge this general picture, the relative importance of CAM in epiphyte communities of moist or wet tropical forests may be exaggerated by these numbers, because they are merely based on the number of species with CAM. Although the proportion of CAM species is sometimes treated, implicitly or even explicitly, as evidence for a similar degree of importance of CAM for the entire epiphyte community and associated functions within the ecosystem (Pierce et al. 2002b), this may be misleading for two reasons. First, abundances in a given community vary strongly between epiphyte species (Zotz et al. 1999; Nieder et al. 2000). While CAM is particularly common among epiphytic orchids, local rarity is also a frequent feature of many members of this family (e.g. Tremblay et al. 1998; Flores-Palacios and Garcia 2001). Secondly, plant biomass may also differ by many orders of magnitude - take, e.g., tiny twig orchids versus massive aroids or large tank bromeliads (Hietz and Hietz-Seifert 1995). Thus, if CAM were particularly common in small and/or rare epiphyte species, the importance of CAM 
within an epiphyte community will be quite different from what could be concluded from species numbers alone.

Consequently, this paper asks the question whether we are using the right currency when studying CAM in epiphytes in the traditional way by screening species. To address this problem, I took advantage of a comprehensive census of an epiphyte community in a tropical lowland forest on the Caribbean slope of Panama (G. Zotz, unpublished data; Zotz and Vollrath 2003). There, all species in a 0.4-ha plot were identified and the size of all individuals determined. Subsequently, the occurrence of CAM was derived from literature data or determined for hitherto unstudied species by stable isotope techniques. The biomass of each individual was estimated by establishing regressions of maximum leaf or stem length and plant dry weight. As expected, the relative importance of CAM differed substantially when expressed on a species, individual or biomass basis.

\section{Materials and methods}

Field site and census work

This study was conducted at the Fort Sherman Canopy Crane site, which is located within the former Fort Sherman area near the Atlantic coast of the Republic of Panama. The average annual rainfall is estimated to be ca. 3,500 $\mathrm{mm}$ (Lerdau and Throop 1999). Canopy height of this primary rain forest is quite variable and reaches a maximum of ca. $40 \mathrm{~m}$. The use of a small gondola allowed access to all strata of the forest.

Each tree in a roughly square area of ca. 0.4 ha was inspected for the occurrence of vascular epiphytes. Not included were woody hemi-epiphytes of the genera Ficus, Coussapoa, Clusia and Havetiopsis and abundant climbing aroids such as Philodendron schottianum. There are a number of species in the Aracaeae, which may grow either as an epiphyte or as secondary hemiepiphyte (Croat 1978). At my study site, both life forms were observed in individuals of Philodendron radiatum and $P$. sagittifolium. In these two species, I included only truly epiphytic individuals.

The following data were collected for each individual: height of attachment (minimum and maximum in creeping species), leaf/frond number, leaf length, stem length, or number of shoots (depending on species). The delimitation of individual plants was sometimes difficult, and we use "individual" sensu Sanford (1968), i.e. as a group of rhizomes and leaves belonging to one species, which forms a clearly delimited stand. With the exception of small seedlings, which could normally not be identified to species, all plant sizes were included in the census.

Species names of flowering plants follow the Flora of Panama Checklist and Index (D'Arcy 1987), authorities for ferns are according to Lellinger (1989) and Croat (1978), for filmy ferns compare also Zotz and Büche (2000). Encyclia aemula was treated as a separate species following Dressler (1993). Voucher specimens are deposited in the herbarium of the Smithsonian Tropical Research Institute, Panama (Tupper Center).

\section{Occurrence of CAM, biomass estimates}

For a large number of species the photosynthetic pathway was already known. In all other cases, leaf/frond samples were collected over the course of several months in 2001 and 2002 from mature plants (compare Zotz and Ziegler 1999) in their natural habitat. After transfer to the laboratory, fresh cross-sections were examined by light microscopy to detect Kranz anatomy. Samples were then dried at $60{ }^{\circ} \mathrm{C}$ for $7-10$ days. The natural abundance of ${ }^{13} \mathrm{C}$ was determined by isotope ratio mass spectrometry (IRMS) at the Institute of Ecology and Conservation Biology, University of Vienna, Vienna, as described by Wanek et al. (2002). Briefly, a continuous flow IRMS system was used, consisting of an elemental analyser (EA 1110; CE instruments, Milan) connected to a gas isotope ratio mass-spectrometer (Finnigan MAT, Bremen, Germany). The $\mathrm{SD}$ of repeated determinations was $0.1 \%$ external precision. The $\delta^{13} \mathrm{C}$ value as a measure of the relative abundance of ${ }^{13} \mathrm{C}$ in a given sample was calculated as:

$\delta^{13} \mathrm{C}(\%)=\left(\frac{{ }^{13} \mathrm{C} /{ }^{12} \mathrm{C} \text { in sample }}{{ }^{13} \mathrm{C} /{ }^{12} \mathrm{C} \text { in standard }}-1\right) \times 1000$

Plant tissues are depleted in ${ }^{13} \mathrm{C}$ compared to atmospheric $\mathrm{CO}_{2}$ which has a $\delta^{13} \mathrm{C}$ value of approximately $-8 \%$ relative to a standard, a belemnite from the Pee Dee formation in South Carolina, USA (PDB). Plants with the $\mathrm{C}_{4}$ photosynthetic pathway typically have $\delta^{13} \mathrm{C}$ values between -9 and $-19 \%$, similar to obligate CAM plants. $\mathrm{C}_{3}$ plants typically have $\mathrm{C}$ isotope ratios in the range of -22 to $-32 \%$ (Troughton 1979). While $\delta^{13} \mathrm{C}$ values at the lower and upper extremes provide clear evidence for the photosynthetic pathway of a sample, intermediate levels cannot be interpreted unequivocally. $\mathrm{CO}_{2}$ near the forest floor may be depleted in ${ }^{13} \mathrm{C}$ because of root respiration and respiratory composition of organic material. As a consequence, $\delta{ }^{13} \mathrm{C}$ values of $\mathrm{C}_{3}$ plants in the understorey can be several \%o more negative than those of canopy leaves. Moreover, $\delta^{13} \mathrm{C}$ values in the range of -21 to $-27 \%$ can still be indicative of some nocturnal $\mathrm{CO}_{2}$ uptake or diel acidity rhythms (Winter et al. 1983; Winter and Holtum 2002). In this paper we follow other studies (e.g. Winter et al. 1983) and consider only $\delta^{13} \mathrm{C}$ values higher (i.e. less negative) than $-20 \%$ as an unambiguous indication of CAM.

With few exceptions (see below) we collected at least five specimens (median=7) per species, which covered the entire size range. All collections were made in the vicinity of our study area. Plant were carefully removed from the substrate with their roots and dried for at least 1 week at $60^{\circ} \mathrm{C}$ to determine total dry mass (subsamples were used in the case of larger plants). Subsequently, best-fit regressions between the variables measured in the field (length of the longest leaf, stem length, number of shoots, respectively) and plant biomass were established using TableCurve (Jandel Scientific, San Rafael, Calif.). Depending on species, power functions, exponential functions or linear regressions were used. Regression coefficients ranged from 0.6 to 0.99 . In the case of rare species we only collected one or two individuals of similar size to those found inside our study plot, or data of species with similar morphology were used. Applying these regressions I obtained a biomass estimate for each individual in the sample plot.

\section{Results}

In the 0.4 ha of lowland forest, I encountered 13,099 individuals belonging to 103 species (Fig. 1, Table 1). The most species-rich family were the Orchidaceae with 45 species. Taken together, ferns and fern-allies accounted for another $28 \%$ of all vascular epiphyte species. The remaining 29 species belonged to five families (Araceae, Bromeliaceae, Cactaceae, Gesneriaceae, Piperaceae). The orchids represented more individuals than all other taxa together, but were less important than aroids and ferns in terms of their contribution to epiphyte biomass.

The $\delta^{13} \mathrm{C}$ values of plant material collected in Fort Sherman ranged from -12.3 to $-34.5 \%$ (Table 1 ). None of these samples showed Kranz anatomy. The possibility that some species may use the $\mathrm{C}_{4}$ photosynthetic pathway can 

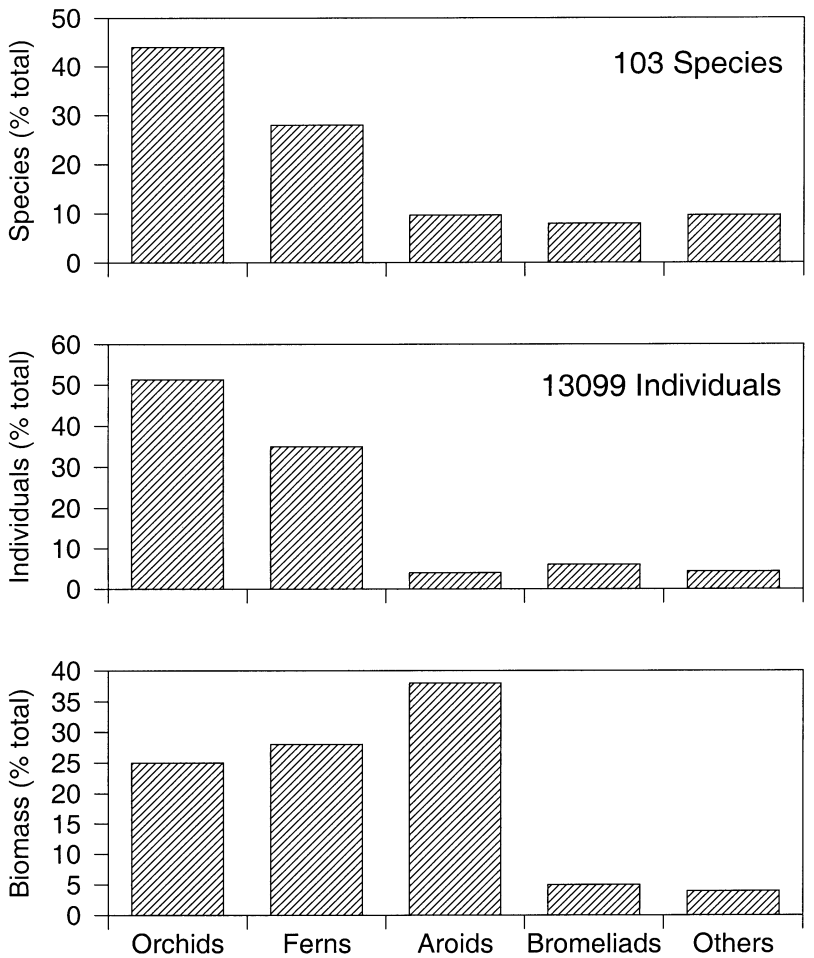

Fig. 1 Relative contribution of different taxa to the total species count, the total individual count and the total biomass of vascular epiphytes in a lowland forest in Panama. The total number of species and individuals in the 0.4-ha study plot are also given

therefore be ruled out. A total of 20 species (19.4\%) showed unequivocal evidence of CAM (Table 1, Fig. 2). Most of these species were orchids (16 species, 80\%), while Bromeliaceae and Cactaceae each contributed two CAM species. Two genera in the Orchidaceae (Jacquiniella Schltr. and Trichocentrum Poepp. \& Endl.) were not previously known to engage in CAM (Smith and Winter 1996). Many CAM species were very rare (Table 1). For example, the orchids Caularthron bilamellatum, Jacquiniella pedunculata, Jacquiniella sp., Lockhartia pittieri, and Maxillaria crassifolium were all found only once or twice. The most common CAM species, Tillandsia bulbosa, was found just 187 times in the study plot, whereas the most common $\mathrm{C}_{3}$ species (Scaphyglottis longicaulis) contributed almost 9 times this number (1,568 individuals). Consequently, the number of individuals with CAM was much lower than the relative proportion of CAM species would suggest: only $3.6 \%$ of all epiphyte individuals showed clear evidence of CAM. The contribution of these plants to the total epiphyte biomass (i.e. $69.6 \mathrm{~kg} \mathrm{ha}^{-1}$ ) was even lower at $2.1 \mathrm{~kg} \mathrm{ha}^{-1}$ (3.0\% of the total).

While total epiphyte biomass was largest at intermediate heights within the forest (Fig. 3), the relative contribution of CAM species reached a maximum in the upper canopy. Similarly, the proportion of CAM biomass increased almost threefold from epiphytes growing on stems $(2.6 \%)$ to those growing on larger branches $(3.1 \%)$ to those attached to small branches and twigs (7.2\%) (Fig. 4).

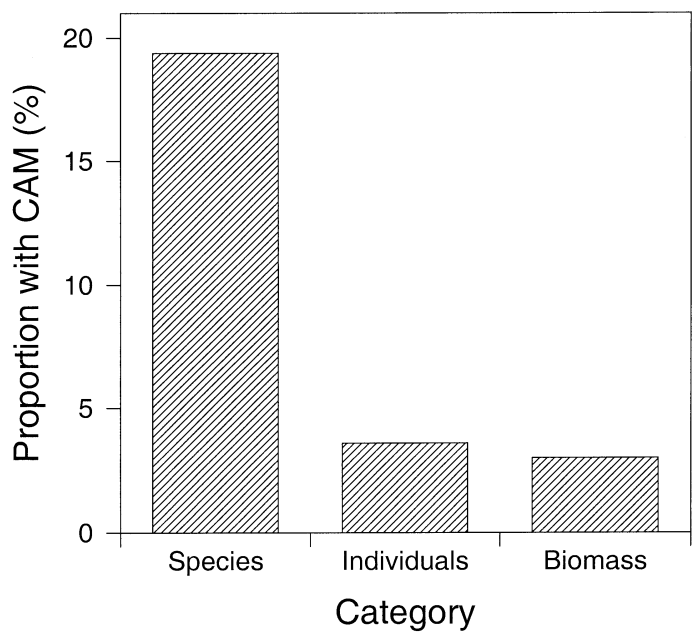

Fig. 2 Relative importance of crassulacean acid metabolism (CAM) in a community of vascular epiphytes as indicated by the proportion of CAM species, the proportion of CAM individuals, and the relative contribution of these individuals to the total biomass of the community. Evidence for the occurrence of CAM is presented in Table 1

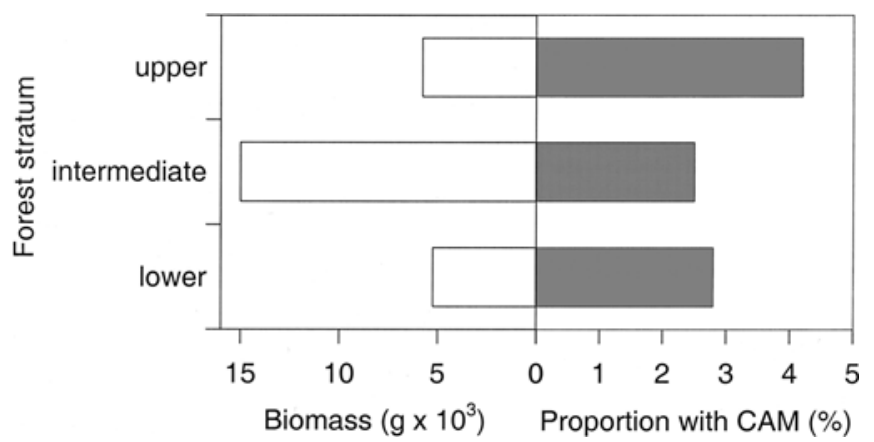

Fig. 3 Vertical stratification of total epiphyte biomass and the relative proportion of CAM biomass (in percent of total biomass) within the forest. Strata are defined as lower $(<10 \mathrm{~m}$ above the ground), intermediate (10-20 m) and upper canopy ( $>20 \mathrm{~m})$

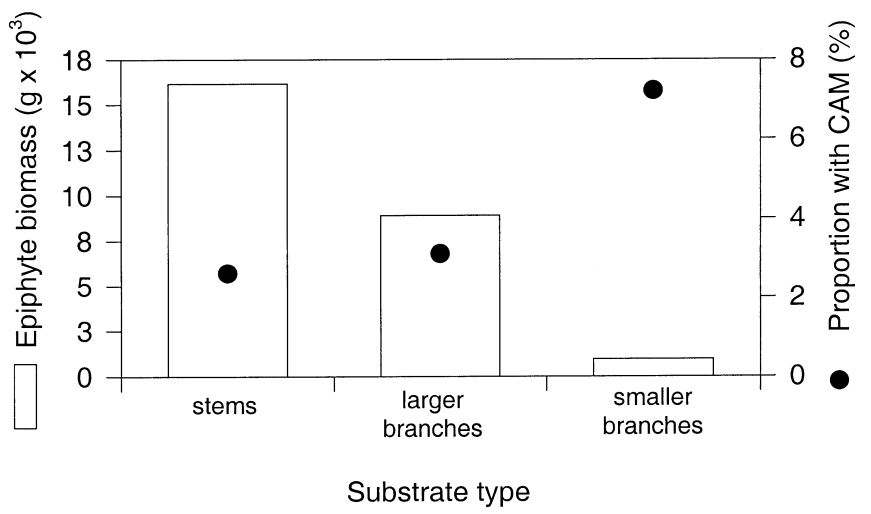

Fig. 4 Distribution of epiphyte biomass and the relative proportion of CAM biomass in relation to the site of attachment. Categories are main tree stem, larger branches $(\geq 5 \mathrm{~cm}$ diameter), and smaller branches $(<5 \mathrm{~cm}$ diameter) 
Table 1 Photosynthetic pathway ${ }^{\mathrm{a}}$, number of individuals and total biomass (g dry mass) of epiphyte species in 0.4 ha of forest at the Fort Sherman Crane Site, Panama. $\delta^{13} \mathrm{C}$ values (\%o) were determined from plants collected in their natural habitat or taken from the literature (Source). $N D$ Not determined

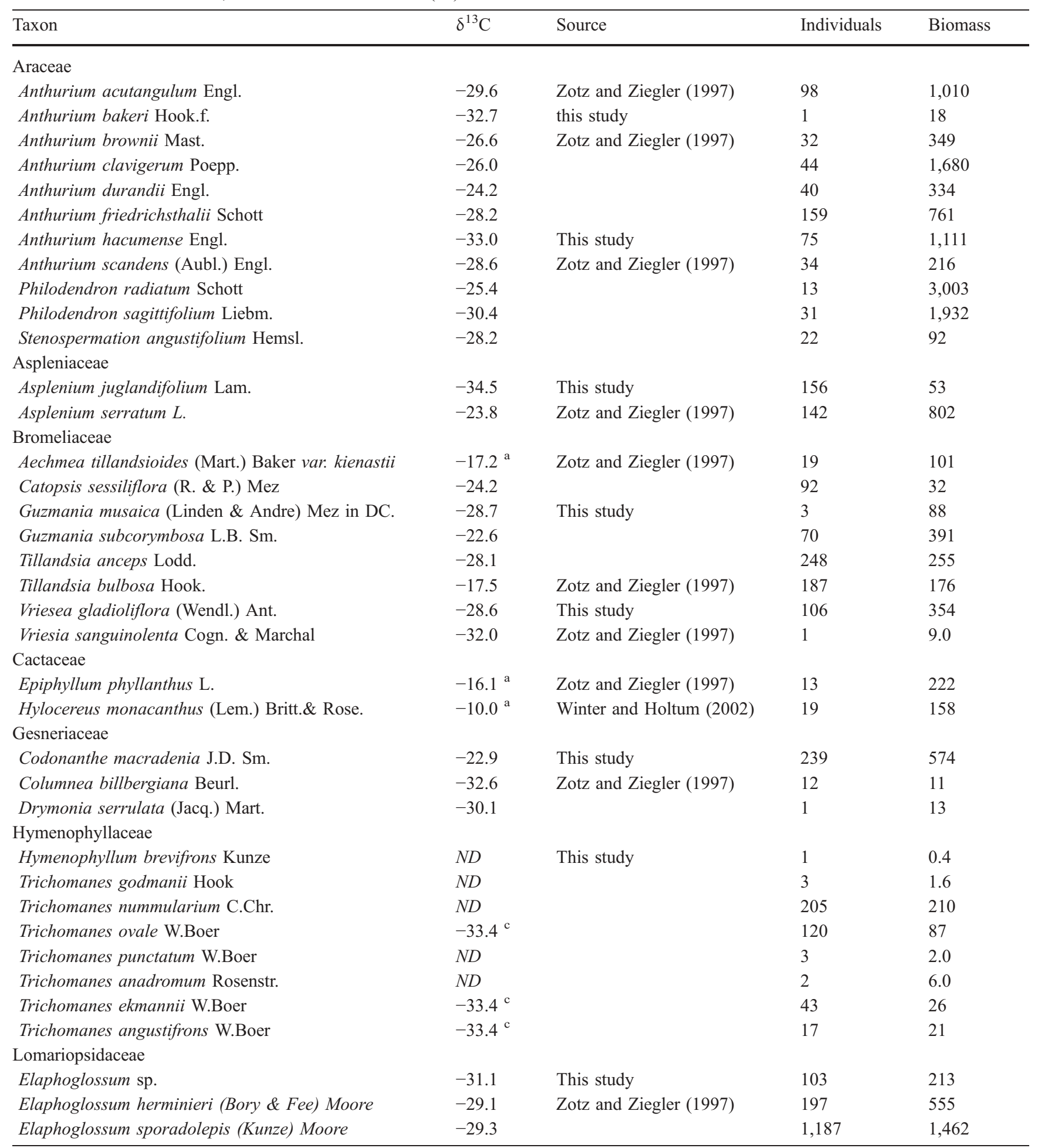


Table 1 (continued)

\begin{tabular}{|c|c|c|c|c|}
\hline Taxon & $\delta^{13} \mathrm{C}$ & Source & Individuals & Biomass \\
\hline \multicolumn{5}{|l|}{ Orchidaceae } \\
\hline Aspasia principissa Reichb.f. & -38.2 & Zotz and Ziegler (1997) & 53 & 48 \\
\hline Catasetum viridiflavum Hook. & -29.3 & & 70 & 526 \\
\hline Caularthron bilamellatum (Reichb.f.) Schult. & $-16.6^{\mathrm{a}}$ & & 1 & 3.4 \\
\hline Dimerandra emarginata (G. Meyer) Hoehne & -28.7 & & 16 & 21 \\
\hline Elleanthus longibracteatus (Lindl. ex Griseb.) Fawc. & -30.1 & & 4 & 13 \\
\hline Encyclia chacaoensis (Reichb.f.) Dressl. & -29.7 & & 16 & 128 \\
\hline Encyclia aemula (Lindl.) Carn. \& Ram. & -28.6 & This study & $-d$ & $-{ }^{d}$ \\
\hline Encyclia chimborazoensis (Schlechter) Dressl. & -27.8 & Zotz and Ziegler (1997) & $-{ }^{d}$ & $-d$ \\
\hline Epidendrum schlechterianum Ames & $-17.6^{\mathrm{a}}$ & & 5 & 0.6 \\
\hline Gongora quinquenervis R. \& P. & -30.5 & & 10 & 41 \\
\hline Jacquiniella pedunculata Dressler $^{\mathrm{b}}$ & $-14.9^{\mathrm{a}}$ & This study & 2 & 0.1 \\
\hline Jacquinella $\mathrm{sp.}$ & $-14.9^{\mathrm{a}}$ & & 1 & 0.2 \\
\hline Kefersteinia sp & -32.8 & & 1 & 1.1 \\
\hline Lockhartia acuta (Lindl.) Reichb.f. & $-20.1^{\mathrm{a}}$ & Zotz and Ziegler (1997) & 58 & 35 \\
\hline Lockhartia pittieri Schltr. $^{\mathrm{b}}$ & $-18.2^{\mathrm{a}}$ & This study & 2 & 0.6 \\
\hline Masdevallia livinstoneana $\mathrm{Rchb} . \mathrm{f}$. & -32.6 & & 45 & 37 \\
\hline Maxillaria crassifolia (Lindl.) Rchb. & $-13.4^{\mathrm{a}}$ & Zotz and Ziegler (1997) & 2 & 7.9 \\
\hline Maxillaria discolor Rchb. f. & -30.8 & This study & 55 & 401 \\
\hline Pleurothallis brighamii S. Wats. & -28.3 & Zotz and Ziegler (1997) & 800 & 231 \\
\hline Pleurothallis grobyi Lindl. & -30.0 & This study & 2 & 0.3 \\
\hline Pleurothallis verecunda Schlechter & $-14.0^{\mathrm{a}}$ & Zotz and Ziegler (1997) & 7 & 13 \\
\hline Polystachya foliosa (Lindl.) Reichb.f. & -27.6 & & 62 & 80 \\
\hline Scaphyglottis behrii Hemsl. & -29.4 & & 1,514 & 1,765 \\
\hline Scaphyglottis longicaulis S. Wats. & -27.9 & & 1,568 & 2,037 \\
\hline Scaphyglottis prolifera Cogn. & -29.3 & This study & 284 & 108 \\
\hline Sobralia fenzliana Rchb.f. & -24.3 & Zotz and Ziegler (1997) & 9 & 28 \\
\hline Sobralia fragans Lindl. & -28.5 & & 169 & 221 \\
\hline Stelis crescentiicola Schlechter & -29.8 & & 119 & 19 \\
\hline Trichocentrum capistratum Rchb.f. ${ }^{\mathrm{b}}$ & $-14.2^{\mathrm{a}}$ & This study & 31 & 3.3 \\
\hline Trichopilia maculata Reichb.f. & -30.2 & Zotz and Ziegler (1997) & 390 & 103 \\
\hline Trichosalpinx orbicularis (Lindl.) Luer. & -30.3 & This study & 12 & 9.1 \\
\hline Trigonidium egertonianum Batem. ex. Lindl. & -30.8 & Zotz and Ziegler (1997) & 60 & 435 \\
\hline \multicolumn{5}{|l|}{ Piperaceae } \\
\hline Peperomia cordulata C. DC. & -24.9 & Zotz and Ziegler (1997) & 5 & 14 \\
\hline Peperomia ebingeri Yunck. & -34.8 & & 2 & 5 \\
\hline Peperomia macrostachya (Vahl) A. Dietr. in L. & -27.3 & & 100 & 114 \\
\hline Peperomia obtusifolia (L.) A.Dietr. & -32.3 & This study & 39 & 23 \\
\hline Peperomia rotundifolia (L.) H.B.K. & -35.0 & Zotz and Ziegler (1997) & 157 & 75 \\
\hline
\end{tabular}


Table 1 (continued)

\begin{tabular}{|c|c|c|c|c|}
\hline Taxon & $\delta^{13} \mathrm{C}$ & Source & Individuals & Biomass \\
\hline \multicolumn{5}{|l|}{ Polypodiaceae } \\
\hline Campyloneurum occultum Gomez & -27.7 & This study & 137 & 51 \\
\hline Campyloneurum phylliditis (L.) K.Presl. & -26.0 & Zotz and Ziegler (1997) & 120 & 771 \\
\hline Dicranoglossum panamense (Christensen) Gómez & -32.7 & & 559 & 210 \\
\hline Microgramma lycopodioides (L.) Copel. & -23.1 & This study & 96 & 93 \\
\hline Microgramma reptans (Cav.) A.R. Sm. & -26.1 & Zotz and Ziegler (1997) & 44 & 43 \\
\hline Niphidium crassifolium (L.) Lellinger & -23.5 & & 478 & 2,175 \\
\hline Pecluma pectinata (L.) MG Price & -27.3 & & 29 & 71 \\
\hline Polypodium costaricense H.Christ & -23.7 & & 5 & 40 \\
\hline Polypodium percussum Cav. & -25.8 & & 170 & 302 \\
\hline Polypodium triseriale Sw. & -27.7 & & 11 & 141 \\
\hline \multicolumn{5}{|l|}{ Selaginellaceae } \\
\hline Huperzia dichotoma (Jacq.) Trevis & -29.5 & This study & 6 & 0.8 \\
\hline \multicolumn{5}{|l|}{ Vittariaceae } \\
\hline Ananthacorus angustifolius (Sw.) Und. \& Max. & -31.2 & Zotz and Ziegler (1997) & 591 & 181 \\
\hline Anetium citrifolium (L.) Splitg. & -33.4 & & 8 & 3.5 \\
\hline Anthrophyum lanceolatum (L.) Kaulf. & -32.3 & This study & 61 & 14 \\
\hline Hecistopteris pumila (Spreng) J.Smith & -31.9 & & 10 & 0.2 \\
\hline Vittaria lineata (L.) J. Sm. & -29.4 & Zotz and Ziegler (1997) & 54 & 182 \\
\hline
\end{tabular}

${ }^{\mathrm{a} C}$ Crassulacean acid metabolism (CAM) present

${ }^{\mathrm{b}} \mathrm{CAM}$ detected in these species for the first time

${ }^{\mathrm{c}}$ Material from three individuals was pooled for analysis

${ }^{\mathrm{d}}$ Non-flowering individuals could not be distinguished from congenerics in the field

\section{Discussion}

Nineteen percent of all epiphyte species or, respectively, $36 \%$ of all epiphytic orchid species showed CAM in this lowland moist forest (Fig. 2, Table 1). The latter figure lies between the 25\% CAM orchids in New Guinean and Australian rain forests (Winter et al. 1983; Earnshaw et al. 1987 ) and the proportion of $40 \%$ in a moist forest in Panama with a much more pronounced dry season (Zotz and Ziegler 1997). Consistent with the original hypothesis, most CAM species of the Fort Sherman epiphyte community were orchids and were relatively small and rare. While in the present study the proportion of CAM species exceeded by far the proportion of individuals with CAM and their relative contribution to the biomass of the epiphyte community (Fig. 2), the reverse may also be true. Zotz et al. (1999) studied the epiphyte community of a particular host tree, Annona glabra, a small tree species with a very open crown in the lowlands of central Panama. In this epiphyte community, which is largely deprived of large aroids and the typical, hygrophytic understorey epiphytes such as filmy ferns (Zotz and Büche 2000), the relative number of individuals with CAM (46\%) was much higher than the proportion of CAM species $(29 \%)$ suggested. Clearly, knowledge of the proportion of species with CAM alone does not allow one to draw unambiguous conclusions on the prevalence of CAM in a given community. The traditional "species approach" may still be valid in large-scale comparisons between vastly differing forest types (Hietz and Hietz-Seifert 1995; Hietz et al. 1999). In extreme cases, e.g. in upper montane forests with a complete absence of CAM species (e.g. Earnshaw et al. 1987) or in tropical dry forests with the opposite situation (Mooney et al. 1989), there is little ambiguity as to the prevalence or the adaptive significance of CAM in an epiphyte community. This clarity strongly diminishes when comparing forests at similar altitude or with rather similar precipitation regimes. Then, the determination of the proportion of CAM species can only be a first step in a study of the importance of $\mathrm{CO}_{2}$ fixation via phosphoenolpyruvate-carboxylase in vascular epiphytes at the community level. Unfortunately, even when counts of individuals and estimates of relative biomass are included (Fig. 2), we still face the problem that some species may possess a certain capacity for nocturnal $\mathrm{CO}_{2}$ fixation that cannot be detected with stable isotope analysis. Consequently, additional measurements of oscillations in titratable acidity and/or diel patterns of $\mathrm{CO}_{2}$ gas exchange are needed (Winter and Holtum 2002). A recent study by Pierce et al. (2002a) suggests, however, that adding these species to $\mathrm{C}_{3}$ plants will introduce a rather small error in our considerations. In their survey of 50 bromeliads, only $13 \%$ of the species with $\mathrm{C}_{3}$-like $\delta^{13} \mathrm{C}$ values showed a rather low degree of nocturnal acidification.

Following the results of earlier studies (Griffiths and Smith 1983; Zotz and Ziegler 1997) I expected a pronounced vertical stratification of $\mathrm{C}_{3}$ and CAM species. 
Although the relative proportion of CAM biomass was indeed highest in the upper forest canopy, the differences between lower and upper strata were rather small (Fig. 3). This limited vertical stratification may be due to the rugged surface of the forest canopy: absolute height above the ground is probably only crudely related to moisture availability. Much more marked differences in the proportion of CAM biomass were observed in respect to the nature of the substrate (Fig. 4). Smaller branches, which presumably constitute drier microhabitats even at intermediate heights within the forest, had a much higher proportion of epiphytic CAM biomass than larger branches and stems.

The biomass of the entire epiphyte community in the studied lowland forest, $66.8 \mathrm{~kg} \mathrm{ha}^{-1}$, is within the range of other reports from lowland forests (Table 2). Remarkably, the highest epiphyte biomass in the tropical lowlands has been reported from a dry forest in Puerto Rico (Murphy and Lugo 1986) and is built up almost completely by CAM plants such as Tillandsia utriculata. In contrast, the generally observed rise in epiphyte biomass with altitude is explained by an increase in annual precipitation (Gentry and Dodson 1987). Even in montane forest, however, vascular epiphytes contribute $<1 \%$ to the total forest biomass (Edwards and Grubb 1977; Tanner 1980). Although the proportion of CAM species decreases with altitude (e.g. Griffiths et al. 1986; Hietz et al. 1999), the much better development of epiphytes in montane forests should still lead to a substantial increase in CAM biomass. The only data set available to test this notion is that of Hietz and Hietz-Seifert (1995; and P. Hietz, unpublished data). The CAM biomass of six epiphyte communities, studied along an altitudinal gradient (720-2,370 $\mathrm{m}$ a.s.l.) in Mexico, averaged $363 \pm 186 \mathrm{~kg} \mathrm{ha}^{-1}$ (average \pm SE). This figure exceeds that of the lowland forest of the present study by $>2$ orders of magnitude. The highest CAM biomass (998 kg ha-1) was detected at intermediate elevations $(1,450 \mathrm{~m}$ a.s.l), in spite of a reduction in the proportion of CAM species from $48 \%$ to $26 \%$ from $720 \mathrm{~m}$ a.s.l. to $1,450 \mathrm{~m}$ a.s.l. The lowest CAM biomass was found at altitudes above ca. $2,000 \mathrm{~m}$ a.s.l., i.e. $<2 \mathrm{~kg} \mathrm{ha}^{-1}$.

Although tropical forest canopies are the global hot spot of CAM in terms of species diversity (Winter and Smith 1996), it is doubtful whether this is also true in terms of biomass (Winter 1985), even when acknowledging the contribution of hemiepiphytes with CAM (Lüttge 1997). However, it is still difficult to address this question quantitatively. On the one hand, the available information on epiphyte biomass has a strong Neotropical bias (Table 2), on the other hand, the data-base for arid nonforest biomes inside and outside the tropics is hardly better than that for tropical forests. It is known that CAM plants are rarely found in deserts, while being frequently abundant in semi-arid areas (Evenari 1985). With few exceptions, quantitative information beyond this general statement is missing. For example, there are no published estimates for CAM biomass in north American deserts (P. S. Nobel, personal communication). Most of the published reports on CAM biomass from other places around the

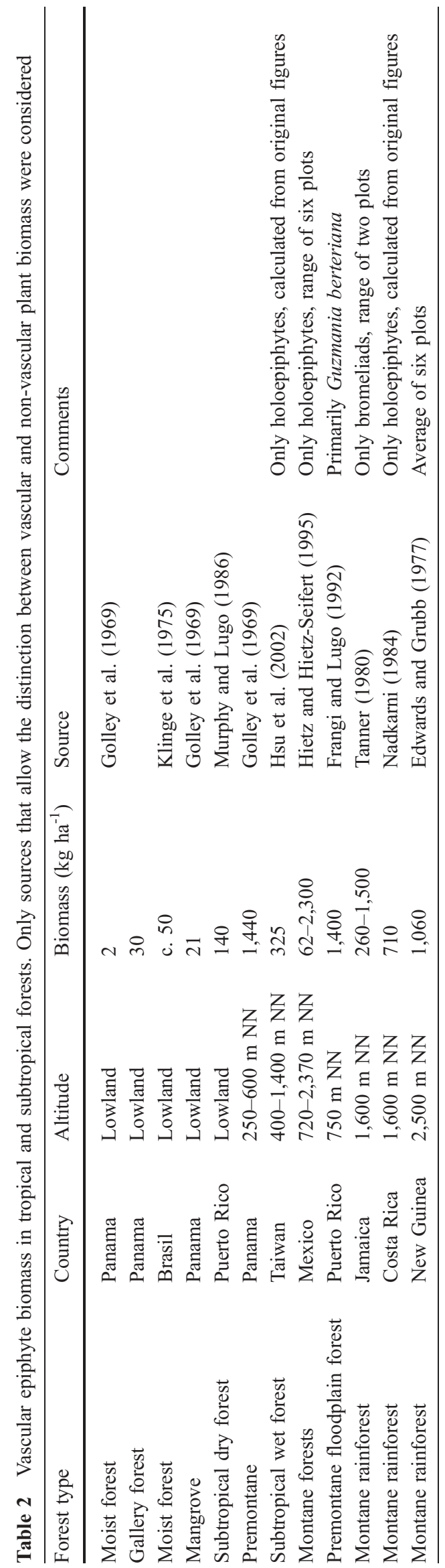


world refer to localized patches of discontinuous vegetation in arid environments (e.g. Liang et al. 1989; Rundel et al. 1997). With such local estimates of CAM standing crop, scaling to a landscape level is virtually impossible, because most of these terrestrial CAM succulents show rather localized, patchy distribution patterns (Smith et al. 1997).

In summary, when studying the prevalence of vascular epiphytes with CAM at the community level, relative species numbers are not a reliable indicator for the number of individuals with CAM or their relative contribution to community biomass. A large percentage of CAM plants are small and rare orchids, hence species numbers may frequently exaggerate the importance of CAM plants in an epiphyte community. Although tropical tree crowns are the global centre of diversity of CAM species, the current data base remains too sketchy as to decide whether most CAM biomass is found in tropical moist and wet forests or rather in semiarid tropical-subtropical vegetation.

Acknowledgements The excellent assistance of S. Schultz (Würzburg, Germany) was essential for the success of this study. Funds came from the Smithsonian Tropical Research Institute (STRI) (Panama), the United Nations Environmental Program, the Deutsche Forschungsgemeinschaft, the FAG, Basel, Switzerland, and the A. F. W. Schimperstiftung, Stuttgart, Germany. Thanks to S. J. Wright, V. Horlyck, J. Herrera and E. Andrade (all STRI) for organising work at the Crane. Help with the identification of epiphytes from D. Lellinger (Washington, D.C.), J. Atwood (Sarasota, USA), R. Dressler (Florida), and C. Galdames (STRI) is appreciated. P. Hietz (Vienna) did not hesitate to dig out decade-old data. Finally, many thanks to W. Wanek (Vienna) for help with the mass spectrometry.

\section{References}

Coutinho LM (1969) Novas observações sôbre a ocorrência do "efeito de de Saussure" e suas relações com a suculência, a temperatura folhear e os movimentos estomáticos. Botanica 24:77-102

Croat TB (1978) Flora of Barro Colorado Island. Stanford University Press, Stanford

D’Arcy WG (1987) Flora of Panama: checklist and index. Missouri Botanical Garden, St. Louis, Mo.

Dressler RL (1981) The orchids. Natural history and classification. Harvard University Press, Cambridge, Mass.

Dressler RL (1993) Field guide to the orchids of Costa Rica and Panama. Cornell University Press, Ithaka, N.Y.

Earnshaw MJ, Winter K, Ziegler H, Stichler W, Cruttwell NEG, Kerenga K, Cribb PJ, Wood J, Croft JR, Carver KA, Gunn TC (1987) Altitudinal changes in the incidence of crassulacean acid metabolism in vascular epiphytes and related life forms in Papua New Guinea. Oecologia 73:566-572

Edwards PJ, Grubb PJ (1977) Studies of mineral cycling in a montane rainforest in New Guinea. I. The distribution of organic matter in the vegetation and soil. J Ecol 65:943-969

Evenari M (1985) Adapations of plants and animals to the desert environment. In: Evenari M, Noy-Meir I, Goodall DW (eds.) Hot deserts and arid shrublands. A. Ecosystems of the world vol 12A. Elsevier, Amsterdam, pp 79-92

Flores-Palacios A, Garcia FJG (2001) Sampling methods for vascular epiphytes: their effectiveness in recording species richness and frequency. Selbyana 22:181-191

Frangi JL, Lugo AE (1992) Ecosystem dynamics of a subtropical floodplain forest. Ecol Monogr 55:351-369
Gentry AH, Dodson CH (1987) Diversity and biogeography of neotropical vascular epiphytes. Ann Mo Bot Gard 74:205-233

Golley FB, McGinnis JT, Clements RG, Child GI, Duever MJ (1969) The structure of tropical forests in Panama and Colombia. BioScience 19:693-696

Griffiths H, Smith JAC (1983) Photosynthetic pathways in the Bromeliaceae of Trinidad: relations between life-forms, habitat preference and the occurrence of CAM. Oecologia 60:176-184

Griffiths H, Lüttge U, Stimmel KH, Crook CE, Griffiths NM, Smith JAC (1986) Comparative ecophysiology of CAM and C3 bromeliads. III. Environmental influences on $\mathrm{CO}_{2}$ assimilation and transpiration. Plant Cell Environ 9:385-393

Hietz P, Hietz-Seifert U (1995) Composition and ecology of vascular epiphyte communities along an altitudinal gradient in central Veracruz, Mexico. J Veg Sci 6:487-498

Hietz P, Wanek W, Popp M (1999) Stable isotopic composition of carbon and nitrogen, and nitrogen content in vascular epiphytes along an altitudinal transect. Plant Cell Environ 22:1435-1443

Hsu C-C, Horng F-W, Kuo C-M (2002) Epiphyte biomass and nutrient capital of a moist subtropical forest in north-eastern Taiwan. J Trop Ecol 18:659-670

Klinge H, Rodriguez WA, Bruning E, Fittkau EJ (1975) Biomass and structure in a Central Amazonian rain forest. In: Golley FB, Medina E (eds) Tropical ecological systems. (Ecological studies vol 11) Springer, Berlin Heidelberg New York, pp $115-122$

Lellinger DB (1989) The ferns and fern-allies of Costa Rica, Panama, and the Chocó. Part I. Psilotaceae through Dicksoniaceae. American Fern Society, Washington, D.C.

Lerdau MT, Throop HL (1999) Isoprene emission and photosynthesis in a tropical forest canopy: implications for model development. Ecol Appl 9:1109-1117

Liang YM, Hazlett DL, Lauenroth WK (1989) Biomass dynamics and water use efficiencies of five plant communities in the shortgrass steppe. Oecologia 80:148-153

Lüttge U (1997) Physiological ecology of tropical plants. Springer, Berlin Heidelberg New York

Mooney HA, Bullock SH, Ehleringer JR (1989) Carbon isotope ratios of plants of a tropical forest in Mexico. Funct Ecol 3:137-142

Murphy PG, Lugo AE (1986) Structure and biomass of a subtropical dry forest in Puerto Rico. Biotropica 18:89-96

Nadkarni NM (1984) Epiphyte biomass and nutrient capital of a neotropical elfin forest. Biotropica 16:249-256

Nieder J, Engwald S, Klawun M, Barthlott W (2000) Spatial distribution of vascular epiphytes (including hemiepiphytes) in a lowland Amazonian rain forest (Surumoni Crane Plot) of Southern Venezuela. Biotropica 32:385-396

Nuernbergk EL (1960) Endogener Rhythmus und $\mathrm{CO}_{2}$-Stoffwechsel bei Pflanzen mit diurnalem Säurerhythmus. Planta 56:28-70

Osmond CB, Winter K, Ziegler H (1982) Functional significance of different pathways of $\mathrm{CO}_{2}$ fixation in photosynthesis. In: Lange OL, Nobel PS, Osmond CB, Ziegler H (eds) Physiological plant ecology. II. Encylopedia of Plant Physiology, new series, vol 12B. Springer, Berlin Heidelberg New York, pp 479-548

Pierce S, Winter K, Griffiths H (2002a) Carbon isotope ratio and the extent of daily CAM use by Bromeliaceae. New Phytol 156:75-83

Pierce S, Winter K, Griffiths H (2002b) The role of CAM in high rainfall cloud forests: an in situ comparison of photosynthetic pathways in Bromeliaceae. Plant Cell Environ 25:1181-1189

Rundel PW, Palma B, Dillon MO, Sharifi MR, Nilsen ET, Boonpragob K (1997) Tillandsia landbeckii in the coastal Atacama Desert of northern Chile. Rev Chil Hist Nat 70:341349

Sanford WW (1968) Distribution of epiphytic orchids in semideciduous tropical forest in southern Nigeria. J Ecol 56:697705 
Smith JAC, Winter K (1996) Taxonomic distribution of crassulacean acid metabolism. In: Winter K, Smith JAC (eds) Crassulacean acid metabolism. Biochemistry, ecophysiology and evolution. (Ecological studies) Springer, Berlin Heidelberg New York, pp 427-436

Smith SD, Monson RK, Anderson JE (1997) Physiological ecology of North American desert plants. Springer, Berlin Heidelberg New York

Tanner EVJ (1980) Studies on the biomass and productivity in a series of montane rain forests in Jamaica. J Ecol 68:573-588

Tremblay RL, Zimmerman JK, Lebrón L, Bayman P, Sastre I, Axelrod F, Alers-García J (1998) Host specifity and low reproductive success in the rare endemic Puerto Rican orchid Lepanthes caritensis. Biol Conserv 85:297-304

Troughton JH (1979) $\delta^{13} \mathrm{C}$ as an indicator of carboxylation reactions. In: Gibbs M, Latzko E (eds) Photosynthesis. II. Photosynthetic carbon metabolism. Encylopaedia of plant physiology, new series, vol 6. Springer, Berlin Heidelberg New York, pp 140-147

Wanek W, Huber W, Arndt SK, Popp M (2002) Mode of photosynthesis during different life stages of hemiepiphytic Clusia species. Funct Plant Biol 29:725-732

Winter K (1985) Crassulacean acid metabolism. In: Barber J, Baker NR (eds) Photosynthetic mechanisms and the environment. Topics in photosynthesis vol 6. Elsevier, Amsterdam, pp 329387
Winter K, Holtum JAM (2002) How closely do the $\delta^{13} \mathrm{C}$ values of crassulacean acid metabolism plants reflect the proportion of $\mathrm{CO}_{2}$ fixed during day and night? Plant Physiol 129:1843-1851

Winter K, Smith JAC (1996) An introduction to crassulacean acid metabolism: biochemical principles and biological diversity. In: Winter K, Smith JAC (eds) Crassulacean acid metabolism. Biochemistry, ecophysiology and evolution. (Ecological studies) Springer, Berlin Heidelberg New York, pp 1-13

Winter K, Wallace BJ, Stocker GC, Roksandic Z (1983) Crassulacean acid metabolism in Australian vascular epiphytes and some related species. Oecologia 57:129-141

Zotz G, Büche M (2000) The epiphytic filmy ferns of a tropical lowland forest-species occurrence and habitat preferences. Ecotropica 6:203-206

Zotz G, Vollrath B (2003) The epiphyte vegetation of the palm, Socratea exorrhiza - correlations with tree size, tree age, and bryophyte cover. J Trop Ecol 19:81-90

Zotz G, Ziegler H (1997) The occurrence of crassulacean acid metabolism among vascular epiphytes from Central Panama. New Phytol 137:223-229

Zotz G, Ziegler H (1999) Size-related differences in carbon isotope discrimination in the epiphytic orchid, Dimerandra emarginata. Naturwissenschaften 86:39-40

Zotz G, Bermejo P, Dietz H (1999) The epiphyte vegetation of Annona glabra on Barro Colorado Island, Panama. J Biogeogr 26:761-776 